\title{
Preclinical efficacy against toxic activities of medically relevant Bothrops sp. (Serpentes: Viperidae) snake venoms by a polyspecific antivenom produced in Mexico
}

\author{
Álvaro Segura ${ }^{1}$, María Herrera ${ }^{1}$, Mariángela $\operatorname{Vargas}^{1}$, Mauren Villalta ${ }^{1}$, Alfredo Uscanga- \\ Reynell $^{2}$, Guillermo León ${ }^{1} \&$ José María Gutiérrez ${ }^{1 *}$ \\ 1. Instituto Clodomiro Picado, Facultad de Microbiología, Universidad de Costa Rica, código postal 11501-2060, San \\ José, Costa Rica; alvaro.seguraruiz@ucr.ac.cr, maria.herrera-v@ucr.ac.cr, mariangela.vargasarroyo@ucr.ac.cr, \\ mauren.villaltaarrieta@ucr.ac.cr, auscangar@birmex.gob.mx, guillermo.leon@ucr.ac.cr, jose.gutierrez@ucr.ac.cr \\ 2. Laboratorios de Biológicos y Reactivos de México S.A. de C.V., código postal 03100, Distrito Federal, México. \\ * Correspondence
}

\section{Received 23-IV-2015. C Corrected 28-VII-2016. Accepted 31-VIII-2016.}

\begin{abstract}
The assessment of the preclinical neutralizing ability of antivenoms in Latin America is necessary to determine their scope of efficacy. This study was aimed at analyzing the neutralizing efficacy of a polyspecific bothropic-crotalic antivenom manufactured by BIRMEX in Mexico against lethal, hemorrhagic, defibrinogenating and in vitro coagulant activities of the venoms of Bothrops jararaca (Brazil), B. atrox (Perú and Colombia), B. diporus (Argentina), B. mattogrossensis (Bolivia), and B. asper (Costa Rica). Standard laboratory tests to determine these activities were used. In agreement with previous studies with bothropic antivenoms in Latin America, a pattern of cross-neutralization of heterologous venoms was observed. However, the antivenom had low neutralizing potency against defibrinogenating effect of the venoms of B. atrox (Colombia) and B. asper (Costa Rica), and failed to neutralize the in vitro coagulant activity of the venom of $B$. asper (Costa Rica) at the highest antivenom/venom ratio tested. It is concluded that, with the exception of coagulant and defibrinogenating activities of $B$. asper (Costa Rica) venom, this antivenom neutralizes toxic effects of various Bothrops sp venoms. Future studies are necessary to assess the efficacy of this antivenom against other viperid venoms. Rev. Biol. Trop. 65 (1): 345-350. Epub 2017 March 01.
\end{abstract}

Key words: snake venom, antivenom, Bothrops, Crotalus, neutralization.

The vast majority of snakebite envenomings occurring in Latin America are inflicted by species of the genus Bothrops (Fan \& Cardoso, 1995; Warrell, 2004; Gutiérrez, 2010), which are distributed from Southern Mexico to Argentina (Campbell \& Lamar, 2004). Depending on their severity, these envenomings are characterized by local tissue damage, i.e. edema, myonecrosis, hemorrhage, blistering, and by systemic alterations, i.e. hemorrhage, coagulopathies, acute kidney injury and cardiovascular shock (Warrell, 2004; Otero-Patiño, 2009; França \& Málaque, 2009). Timely parenteral administration of antivenom is the only validated treatment for these envenomings. Diverse manufacturing laboratories in the region produce either monospecific or polyspecific bothropic antivenoms (Gutiérrez, Higashi, Wen, \& Burnouf, 2007). The immunization mixtures used to generate these antivenoms greatly vary between laboratories. For instance, a polyspecific bothropic antivenom is manufacture by several laboratories in Brazil, using a mixture of the venoms of Bothrops jararaca, B. jararacussu, B. moojeni, $B$. neuwiedii, and B. alternatus as antigen (Cardoso, Yamaguchi, \& Moura da Silva, 2009). On the other hand, a polyspecific antivenom produced in Costa Rica is generated by immunizing horses with a mixture of venoms of 
Bothrops asper, Crotalus simus and Lachesis stenophrys (Segura et al., 2010).

There are situations in which antivenoms have to be imported from other countries in Latin America, either because there is no local production or because the national stocks of these immunobiologicals are insufficient. In these circumstances, it is highly relevant to ensure that antivenoms being imported are indeed effective in the neutralization of venoms of the most important snakes of the country. Hence, the preclinical assessment of the ability of antivenoms to neutralize venoms from species distributed in other countries in the region is important in order to have a knowledgebased platform for the distribution of antivenoms between countries in Latin America, often under the coordination of the Pan American Health Organization (PAHO) (Gutiérrez, 2014). Several studies have been performed in the past for assessing the preclinical efficacy of antivenoms in Latin America (see for example Otero et al., 1995; Gutiérrez, Rojas, Bogarín, \& Lomonte, 1996; de Roodt, Dolab, Fernández, Segre, \& Hajos, 1998; Bogarín et al., 2000). One of the most comprehensive analysis of the preclinical efficacy of antivenoms against venoms of various species of Bothrops sp. evaluated seven polyspecific antivenoms produced in Argentina, Brazil, Peru, Bolivia, Colombia and Costa Rica against the venoms of five species of Bothrops from different countries (Segura et al., 2010). This and other studies have underscored a widespread pattern of crossneutralization of antivenoms against heterologous Bothrops sp. venoms. The present report extends these observations by investigating the preclinical efficacy of an antivenom manufactured in Mexico when confronted with the venoms of species of Bothrops from Brazil, Peru, Colombia, Argentina, Bolivia and Costa Rica.

\section{MATERIALS AND METHODS}

Venoms: The venoms of the following species were utilized: (a) Bothrops diporus (previously classified as B. neuwiedi) (Argentina), provided by Centro Nacional de Control de Calidad de Biológicos (CNCCB)-ANLIS "Dr Carlos G. Malbrán”, Buenos Aires; (b) $B$. mattogrossensis) (previously classified as $B$. neuwiedi) (Bolivia), provided by the Instituto Nacional de Laboratorios de Salud (INLASA), La Paz; (c) B. jararaca (Brazil), provided by Instituto Butantan, Sao Paulo; (d) B. atrox (Peru), provided by Instituto Nacional de Salud (INS), Lima; (e) B. atrox (Colombia), provided by Instituto Nacional de Salud (INS), Bogotá; and (f) B. asper (Costa Rica), provided by Instituto Clodomiro Picado, Universidad de Costa Rica, San José. These venoms corresponded to the same pooled samples utilized in the study of Segura et al. (2010).

Antivenom: The antivenom tested is manufactured in Mexico by Laboratorios de Biológicos y Reactivos de México S.A. (BIRMEX; batch sv-162; in some experiments two additional batches were used: SV-165 and $\mathrm{SV}-187)$. This antivenom is produced from the plasma of horses immunized with a mixture of the venoms of $B$. asper and Crotalus basiliscus obtained from specimens collected in Mexico and kept at the serpentarium of BIRMEX. Fractionation of hyperimmune plasma is achieved by digestion of plasma proteins with pepsin at acid $\mathrm{pH}$ (Pope, 1939) and ammonium sulfate precipitation. It is a freeze-dried preparation composed of $\left.\mathrm{F}(\mathrm{ab})_{2}\right)_{2}$ antibody fragments.

Neutralization of toxic activities: The following toxic activities of venoms were investigated: lethal (by the intraperitoneal route), hemorrhagic, defibrinogenating, and in vitro coagulant activities. The methods used for the characterization of the toxic activities of these venoms were described in a previous publication (Segura et al., 2010), and the same procedures were followed in the present work. For the analysis of the neutralization of these effects, a fixed amount of venom, which varies according to the effect to be studied, was incubated with various dilutions of the antivenom. Incubations were performed for 30 $\mathrm{min}$ at $37{ }^{\circ} \mathrm{C}$. Venoms were dissolved in 0.12 $\mathrm{M} \mathrm{NaCl}, 0.04 \mathrm{M}$ phosphate, $\mathrm{pH} 7.2$ (PBS). 
Controls included venom incubated with PBS without antivenom. After incubation, aliquots of the mixtures, containing a 'challenge dose' of venom, were tested in the corresponding assay systems described by Segura et al. (2010). The 'challenge doses' used were: For lethality, four Median Lethal Doses $\left(\mathrm{LD}_{50} \mathrm{~s}\right)$; for hemorrhage, five Minimum Hemorrhagic Doses (MHDs); for defibrinogenation, two Minimum Defibrinogenating Doses (MDDs); and for in vitro coagulation, two Minimum Coagulant Doses (MCDs). For lethal and hemorrhagic effects, the neutralizing efficacy was expressed as Median Effective Dose $\left(\mathrm{ED}_{50}\right)$, i.e. the ratio $\mu \mathrm{L}$ antivenom $/ \mathrm{mg}$ venom in which the effect of the venom alone was reduced by $50 \%$ (Gutiérrez et al., 1990). In the case of neutralization of lethality, results were also expressed as the ratio $\mathrm{mg}$ venom $/ \mathrm{mL}$ antivenom. $\mathrm{ED}_{50}$ for lethality was estimated by probits (Finney, 1971). For defibrinogenating and in vitro coagulant activities, neutralization was expressed as Effective Dose (ED), as defined by Gené, Roy, Rojas, Gutiérrez and Cerdas (1989) and Segura et al. (2010).

\section{RESULTS}

The six venoms studied induced lethal, hemorrhagic, defibrinogenating and in vitro coagulant activities, as previously described
(Segura et al., 2010). Since the venom pools used were the same as those utilized by Segura et al. (2010), the results of these toxicity tests are not reported here, and the reader is referred to this previous study. Regarding neutralization, the polyspecific antivenom of BIRMEX neutralized the lethal activity of all venoms tested, albeit with varying $\mathrm{ED}_{50} \mathrm{~s}$ depending on the venom (Table 1). Highest neutralization was achieved against the venoms of $B$. diporus (Argentina) and B. mattogrossensis (Bolivia), both of which were previously classified as $B$. neuwiedi, whereas the lowest neutralization was against the venom of $B$. atrox from Peru (Table 1). Antivenom was also effective in the neutralization of hemorrhagic activity of all venoms tested. Highest neutralization was achieved against the venoms of $B$. asper (Costa Rica) and B. atrox (Colombia), whereas the lowest neutralization was against the venom of B. atrox (Peru) (Table 1). Antivenom neutralized defibrinogenating activity of the venoms of B. diporus (Argentina), B. atrox (Peru), $B$. mattogrossensis (Bolivia) and B. jararaca (Brasil); in contrast, it required a high antivenom/venom ratio $(4000 \mu \mathrm{L}$ antivenom $/ \mathrm{mg}$ venom) to neutralize defibrinogenating activity of the venoms of B. atrox (Colombia) and $B$. asper (Costa Rica) (Table 1). Regarding in vitro coagulant activity, antivenom was effective in neutralizing the venoms of $B$. atrox

TABLE 1

Neutralization of toxic activities of Bothrops sp venoms by BIRMEX polyspecific antivenom ${ }^{\text {a }}$

\begin{tabular}{lccccc}
\multicolumn{1}{c}{ Venom } & $\begin{array}{c}\text { Lethality } \\
(\mathrm{mg} \mathrm{V} / \mathrm{mL} \mathrm{AV})^{\mathrm{b}}\end{array}$ & $\begin{array}{c}\text { Lethality } \\
(\mu \mathrm{L} \mathrm{AV} / \mathrm{mg} \mathrm{V})^{\mathrm{b}}\end{array}$ & $\begin{array}{c}\text { Hemorrhagic } \\
(\mu \mathrm{L} \mathrm{AV} / \mathrm{mg} \mathrm{V})\end{array}$ & $\begin{array}{c}\text { Defibrinogenating } \\
(\mu \mathrm{L} \mathrm{AV} / \mathrm{mg} \mathrm{V})\end{array}$ & $\begin{array}{c}\text { Coagulant } \\
(\mu \mathrm{L} \mathrm{AV} / \mathrm{mg} \mathrm{V})\end{array}$ \\
B. atrox (Peru) & $1.70(1.28-2.16)$ & $588(463-781)$ & $825 \pm 93$ & 2000 & $425 \pm 18$ \\
B. atrox (Colombia) & $3.12(2.31-4.22)$ & $321(237-433)$ & $125 \pm 18$ & 4000 & $1096 \pm 49$ \\
B. asper (Costa Rica) & $2.34(1.77-2.29)$ & $427(437-565)$ & $136 \pm 6$ & 4000 & $>4000$ \\
B. diporus (Argentina) & $6.75(5.16-8.82)$ & $148(113-194)$ & $151 \pm 1$ & 1000 & $385 \pm 7$ \\
B. jararaca (Brazil) & $3.48(2.36-4.62)$ & $287(216-424)$ & $279 \pm 12$ & 1000 & $438 \pm 22$ \\
B. mattogrossensis & $4.44(2.56-7.70)$ & $225(130-391)$ & $210 \pm 7$ & 1000 & $854 \pm 35$ \\
(Bolivia) & & & & & \\
\hline
\end{tabular}

${ }^{a}$ Neutralization of lethal, hemorrhagic and coagulant activities is expressed as Median Effective Dose $\left(\mathrm{ED}_{50}\right)$, whereas neutralization of defibrinogenating activity is expressed as Effective Dose (ED) (see the text for details). Results are presented as mean \pm S.D. $(n=4)$, except in lethality where the $95 \%$ confidence limits are included in parentheses.

${ }^{b}$ Neutralization of lethality is presented in two different ways: $\mathrm{mg}$ venom per $\mathrm{mL}$ antivenom, and $\mu \mathrm{L}$ antivenom per mg venom. 
(Peru and Colombia), B. diporus (Argentina), B. mattogrossensis (Bolivia), and B. jararaca (Brasil), being ineffective, at the highest antivenom/venom ratio tested $(4000 \mu \mathrm{L}$ antivenom $/ \mathrm{mg}$ venom), to neutralize coagulant activity of the venom of $B$. asper from Costa Rica (Table 1). In order to corroborate this finding observed with the antivenom batch used (batch SV-162), two additional batches (SV165 and SV-187) were tested for their ability to neutralize coagulant activity of Costa Rican $B$. asper venom. These two batches also failed to neutralize this effect at the highest antivenom/ venom ratio tested.

\section{DISCUSSION}

Our results corroborate, for the polyspecific crotaline antivenom produced in Mexico by BIRMEX, the extensive cross-reactivity described for bothropic antivenoms in Latin America (Bogarín et al., 2000; Segura et al., 2010). In this case, when using the venoms of B. asper and C. basiliscus from Mexico in the immunizing mixture, the antivenom generated is effective for the neutralization of the four activities in the venoms of the South American species $B$. jararaca, B. diporus, B. mattogrossensis and $B$. atrox (Peru). The neutralization of lethality is the gold standard in the preclinical assessment of antivenom potency; in this regard, it is noteworthy that BIRMEX antivenom has a higher neutralizing ability of lethal effect of the venoms of $B$. asper (Mexico) (Segura et al., 2012), B. diporus, B. jararaca, $B$. atrox (Colombia), and B. mattogrossensis than against the venoms of $B$. asper (Costa Rica) and B. atrox (Peru). In contrast with other bothropic polyspecific antivenoms analyzed in previous works, BIRMEX antivenom has a relatively low neutralizing ability of defibrinogenating activity of the venoms of $B$. asper from Costa Rica and B. atrox from Colombia, and failed to neutralize in vitro coagulant activity of Costa Rican B. asper venom, at the highest antivenom/venom ratio used in this study (4000 $\mu \mathrm{L}$ antivenom/mg venom).

A previous study showed that BIRMEX antivenom was highly effective in the neutralization of the venom of $B$. asper from Mexico, which is used in the immunizing mixture (Segura et al., 2012). The values of $\mathrm{ED}_{50}$ were $188 \pm 27 \mu \mathrm{L}$ antivenom $/ \mathrm{mg}$ venom and $129 \pm 4 \mu \mathrm{L}$ antivenom $/ \mathrm{mg}$ venom for lethal and hemorrhagic activities, respectively, and the values of ED were $1135 \pm 19 \mu \mathrm{L}$ antivenom $/ \mathrm{mg}$ venom and $2000 \mu \mathrm{L}$ antivenom $/ \mathrm{mg}$ venom for in vitro coagulant and defibrinogenating actities, respectively (Segura et al., 2012). Moreover, in this study it was shown that BIRMEX antivenom was more effective in the neutralization of in vitro coagulant activity of the venom of $B$. asper from Mexico, as compared to the venom of $B$. asper from Costa Rica (Segura et al., 2012). This is likely to reveal differences in the immunological properties of procoagulant toxins in the venoms of B. asper from Mexico and Costa Rica, an issue that deserves further investigations. Owing to the relevance of coagulant and defibrinogenating activities in the overall pathophysiology of Bothrops sp. envenoming, these results suggest that BIRMEX antivenom may not be effective for the control of coagulopathies in envenomings by $B$. asper from Costa Rica, and may have a low efficacy for controlling defibrinogenation in envenomings by $B$. atrox from Colombia, probably requiring high volumes of antivenom to achieve therapeutic success. As a way to confront this problem, the venom mixtures used for horse immunization could be enriched with venoms of specimens of $B$. asper collected in countries other than Mexico.

In conclusion, the polyspecific bothropiccrotalic antivenom manufactured by BIRMEX in Mexico presents a pattern of cross-neutralization when confronted with heterologous Bothrops sp. venoms from various South American countries. However, this antivenom shows a low neutralizing ability against defibrinogenating and in vitro coagulant activities of the venom of $B$. asper from Costa Rica. 


\section{ACKNOWLEDGMENTS}

The authors thank Instituto Butantan (Brazil), Instituto Nacional de Salud (Perú), Instituto Nacional de Laboratorios de Salud (Bolivia), Instituto Nacional de Salud (Colombia), and Centro Nacional de Control de Calidad de Biológicos (CNCCB)-ANLIS "Dr Carlos G. Malbrán" (Argentina) for providing some of the venoms used in this investigation. This study was supported by Vicerrectoría de Investigación, Universidad de Costa Rica (project 741-B2-091).

\section{RESUMEN}

Eficacia de un antiveneno poliespecífico producido en México para neutralizar, a nivel preclínico, las actividades tóxicas de venenos de Bothrops sp (Serpentes: Viperidae) de importancia médica. Es necesario estudiar a nivel preclínico la capacidad neutralizante de los antivenenos producidos en América Latina, para conocer su espectro de cobertura. En este estudio se analizó la eficacia preclínica de un antiveneno poliespecífico botrópico-crotálico producido por BIRMEX, en México, para neutralizar los efectos letal, hemorrágico, desfibrinogenante y coagulante in vitro de los venenos de Bothrops jararaca (Brasil), B. atrox (Perú y Colombia), B. diporus (Argentina), B. mattogrossensis (Bolivia) y B. asper (Costa Rica). Se emplearon metodologías de laboratorio estándar en los análisis. En consonancia con estudios anteriores con diversos antivenenos botrópicos en América Latina, se observó un amplio patrón de neutralización de estos venenos heterólogos en la mayoría de los efectos estudiados. Sin embargo, el antiveneno mostró una baja capacidad neutralizante contra el efecto desfibrinogenante de los venenos de B. atrox (Colombia) y B. asper (Costa Rica) $\mathrm{y}$ no neutralizó la actividad coagulante in vitro del veneno de B. asper (Costa Rica) a la máxima razón antiveneno/ veneno empleada.

Palabras clave: veneno de serpiente, antiveneno, Bothrops, Crotalus, neutralización.

\section{REFERENCES}

Bogarín, G., Morais, J. F., Yamaguchi, I. K., Stephano, M. A., Marcelino, J. R., Nishikawa, A. K., Guidolin, R., Rojas, G., Higashi, H. G., \& Gutiérrez, J. M. (2000). Neutralization of crotaline snake venoms from Central and South America by antivenoms produced in Brazil and Costa Rica. Toxicon, 38, 1429-1441.
Campbell, J. A., \& Lamar, W. W. (2004). The Venomous Reptiles of the Western Hemisphere. Ithaca: Cornell University Press.

Cardoso, D. F., Yamaguchi, I. K., \& Moura da Silva, A. M. (2009). Produçao de soros antitoxinas e perspectivas de modernizaçao por técnicas de biología molecular. In J. L. C. Cardoso, F. O. S. França, F. H. Wen, C. M. S. Málaque, \& V. Haddad (Eds.), Animais peçonhentos no Brasil. Biologia, clínica e terapêutica dos acidentes (2 ${ }^{\mathrm{a}}$ Ed., pp. 419-431). Sao Paulo: Sarvier.

de Roodt, A. R., Dolab, J. A., Fernández, T., Segre, L., \& Hajos, S. E. (1998). Cross-reactivity and heterologous neutralization of crotaline antivenoms used in Argentina. Toxicon, 36, 1025-1038.

Fan, H. W., \& Cardoso, J. L. (1995) Clinical toxicology of snake bites in South America. In J. Meier \& J. White (Eds.), Handbook of clinical toxicology of animal venoms and poisons (pp. 667-688). Boca Raton: CRC Press.

Finney, D. J. (1971). Probit analysis. Cambridge: Cambridge University Press.

França, F. O. S., \& Málaque, C. M. S. (2009). Acidente botrópico. In J. L. C. Cardoso, F. O. S. França, F. H. Wen, C. M. S. Málaque, \& V. Haddad (Eds.), Animais peçonhentos no Brasil. Biologia, clínica e terapéutica dos accidentes ( $2^{\mathrm{a}}$ Ed., pp. 81-95). Sao Paulo: Sarvier.

Gené, J. A., Roy, A., Rojas, G., Gutiérrez, J. M., \& Cerdas, L. (1989). Comparative study on coagulant, defibrinating, fibrinolytic and fibrinogenolytic activities of Costa Rican crotaline snake venoms and their neutralization by a polyvalent antivenom. Toxicon, 27, 841-848.

Gutiérrez, J. M. (2010). Snakebite envenomation in Central America. In S. P. Mackessy (Ed.), Handbook of venoms and toxins of reptiles (pp. 491-507). Boca Raton: CRC Press.

Gutiérrez, J. M. (2014). Reducing the impact of snakebite envenoming in Latin America and the Caribbean: achievements and challenges ahead. Transactions of the Royal Society of Tropical Medicine and Hygiene, 108, 530-537.

Gutiérrez, J. M., Higashi, H. G., Wen, F. H., \& Burnouf, T. (2007). Strengthening antivenom production in Central and South American public laboratories: report of a workshop. Toxicon, 49, 30-35.

Gutiérrez, J. M., Rojas, G., Bogarín, G., \& Lomonte, B. (1996). Evaluation of the neutralizing ability of antivenoms for the treatment of snake bite envenoming in Central America. In C. Bon \& M. Goyffon (Eds.), Envenomings and their treatment (pp. 223-231). Lyon: Fondation Marcel Mérieux. 
Gutiérrez, J. M., Rojas, G., Lomonte, B., Gené, J. A., Chaves, F., Alvarado, J., \& Rojas, E. (1990). Standardization of assays for testing the neutralizing ability of antivenoms. Toxicon, 28, 1127-1129.

Otero, R., Núñez, V., Osorio, R. G., Gutiérrez, J. M., Giraldo, C. A., \& Posada, L. E. (1995). Ability of six Latin American antivenoms to neutralize the venom of mapaná equis (Bothrops atrox) from Antioquia and Chocó (Colombia). Toxicon, 33, 809-815.

Otero-Patiño, R. (2009). Epidemiological, clinical and therapeutic aspects of Bothrops asper bites. Toxicon, 54, 998-1011.

Pope, C. G. (1939). The action of proteolytic enzymes on the antitoxins and proteins in immune sera. I. True digestion of the proteins. British Journal of Experimental Pathology, 20, 132-149.

Segura, Á., Castillo, M. C., Núñez, V., Yarlequé, A., Gonçalves, L. R. C., Villalta, M., Bonilla, C., Herrera, M., Vargas, M., Fernández, M., Yano, M. Y., Araújo,
H. P., Boller, M. A., León, P., Tintaya, B., Sano-Martins, I. S., Gómez, A., Fernández, G. P., Geoghegan, P., Higashi, H. G., León, G., \& Gutiérrez, J. M. (2010). Preclinical assessment of the neutralizing capacity of antivenoms produced in six Latin American countries against medically-relevant Bothrops snake venoms. Toxicon, 56, 980-989.

Segura, Á., Herrera, M., Villalta, M., Vargas, M., UscangaReynell, A., Ponce de León-Rosales, S., JiménezCorona, M. E., Reta-Mares, J. F., Gutiérrez, J. M., \& León, G. (2012). Venom of Bothrops asper from Mexico and Costa Rica: Intraspecific variation and cross-neutralization by antivenoms. Toxicon, 59, 158-162.

Warrell, D. A. (2004) Snakebites in Central and South America: Epidemiology, clinical features, and clinical management. In J. A. Campbell \& W. W. Lamar (Eds.), The venomous reptiles of the Western Hemisphere (Vol I, pp. 709-761). Ithaca: Cornell University Press. 